\title{
Lessons from the Synod of Dordrecht (1618-1619): A missional hermeneutic for the decolonisation and Africanisation of the curriculum
}

Author:
Pieter H.J. Labuschagne ${ }^{1}$
Affiliation:
${ }^{1}$ Missiology Department of
South African Tehological
Seminary, Bryanston,
South Africa
Corresponding author:
Pieter Labuschagne,
pieter@sats.edu.za
Dates:
Received: 05 May 2019
Accepted: 25 July 2019
Published: 23 Oct. 2019
How to cite this article:
Labuschagne, P.H.J., 2019,
'Lessons from the Synod of
Dordrecht (1618-1619):
A missional hermeneutic
for the decolonisation and
to read online.
Africanisation of the
curriculum, In die Skriflig
53(3), a2482. https://doi.org/
10.4102/ids.v53i3.2482
Copyright:
(C) 2019. The Authors.
Licensee: AOSIS. This work
is licensed under the
Creative Commons
Attribution License.

About 400 years ago, the status quo of the church in the Netherlands was threatened by the Remonstrant uprising, which was met with vehement reaction from Calvinists. The situation got out of hand when the parties failed to find an amicable resolution, which led Prince Maurice of Nassau to interject and call a synod to resolve the conflict. Maurice switched sides shortly before the start of the Synod to assure maximum economic and political gain. Due to this political influence, the outcome of the Synod was practically determined even before the first session started: the Remonstrants were defeated, Calvinism was imposed, and Maurice got his political victory. Regrettably the failure of the church to deal with an internal matter, led to interference by the state. Although the Synod of Dordrecht had its unique context and raison-d'être, it was not different to the way in which many church conflicts have been handled throughout history. It is important to learn lessons from the Synod of Dordrecht so that we can handle contemporary challenges better. One such challenge is the call for the decolonisation and Africanisation of education in South Africa - also of the theological curriculum. When opposing parties do not listen to each other, there is no chance of resolving their differences. There are lessons to be learnt from the Synod of Dordrecht and from intercultural engagement that can help us to find an approach to our problems that is collaborative and not patronising. Instead of arguing the matter from opposite extremes, we need to create an epistemic community of role players, ensuring meaningful encounters. This could serve as the basis of a missional hermeneutic for change; a missional hermeneutic of mutual acceptance and collaboration. The theological differences, expressed at the Synod of Dordrecht, is still passionately debated today and causes as much division as the original conflict. If we deal with contemporary issues in the same way as the Synod of Dordrecht did, we cannot expect different results. A missional hermeneutic, based on the missio Dei with mutual acceptance and collaboration, is needed.

Keywords: Missional hermeneutics; Intercultural; Decolonisation; Africanisation; Synod of Dordrecht.

\section{Introduction}

\section{Context and purpose of the study}

This article looks briefly at the Synod of Dordrecht (1618-1619) and how events unfolded, leading up to the Synod and what the outcome was. What should have been a church debate, became an economic and political endeavour. Instead of the two opposing sides of Christian dogma working out their problems internally, each stubbornly stood their ground. A lesson that we learn from this is that differences of opinion cannot be resolved when an attitude of superiority is embraced. The outcome was that their dispute was resolved with the aid of an outside source: the state.

One of the pressing challenges that we face today is the call for the decolonisation and Africanisation of education in South Africa - also of the theology curriculum. This challenge juxtaposes two powerful opponents: Africa and colonialism. A lesson from Dordrecht is that there is no place for superiority and dominance, forcing one's views down on another. It is important to find a resolution to the problem that includes best practices for engaging with those who have different views to our own.

It should be noted that the debate in Dordrecht was a doctrinal one about peoples' beliefs. This was clearly a theological matter, which should have been dealt with by the church. Due to the stubborn unwillingness to make space for one another, the two groups were unable to resolve 
their conflict and the state intervened - for their own economic and political benefit. In the case of decolonisation, the matter is not dogma or religion, but rather culture and politics. Foundationally, these two situations presuppose different epistemic communities that are qualified to find the best solution in each case. Of vital importance, in both cases, is that the right role players must engaged to resolve the matter.

\section{Method}

We start out with a literary study, examining the events and circumstances surrounding the Synod of Dordrecht. The failure of the church to deal with an internal matter and the subsequent involvement of the state are examined. This stimulates reflections on how the Remonstrant or Calvinist debacle could have been resolved better. Secondly, attention is given to decolonisation and Africanisation to better understand the intricacies of the problem. Thirdly, basic principles of cross-cultural engagement are examined, which can assist in resolving differences. Basic building-blocks of meaningful encounters between people with differing views are identified and related to a missional hermeneutic for change.

\section{A warning for today}

The outcome of the Synod of Dordrecht and the victory of the Calvinists were short-lived. The Remonstrants returned to the Netherlands, settled and planted churches under the banner of Arminianism. Four hundred years later, the matter is still passionately debated and still brings division. If we deal in the same way with the issues facing the theological curriculum, we cannot expect different results. A missional hermeneutic of mutual understanding and collaboration, based on the missio Dei, is needed. We need to give heed to different points of view about decolonisation and Africanisation.

\section{The Synod of Dordrecht (1618-1619) Theology in turmoil}

One of the great markers of the start of the Reformation was when Martin Luther nailed his 95 theses to the church door in Wittenberg on 31 October 1517. In a similar fashion, the Synod of Dordrecht in 1618-1619 is one of the markers of the end of the Reformation (Dreyer 1997:1206). The beginning and the end were almost equally tumultuous with theological powers colliding in spectacular fashion. In the build-up to both, different theological emphases polarised the respective faith-communities.

This period of roughly 100 years between 1517 and 1618 was characterised by political, economic and religious reforms and many statements of faith were formulated in the Reformed churches of Germany, England, France, Switzerland, Hungary and the Netherlands (Dreyer 1997:1206). Such declarations grew from the necessity of standardisation by independent churches of their Reformed orientation, regarding their preaching, teaching, catechism and defence against the Catholic Church.

Unlike these, the Canons of Dort was at the outset not a general creed of Reformed theology; it was a document responding to the Arminian Remonstrance of 1610 - the culmination of disagreements that continued throughout the preceding 100 years of Reformation. The debate was driven to a climax when Arminius was appointed as professor at the University of Leiden in 1603 where serious conflict arose between him and Franciscus Gomarus about the doctrine of election (Botha 2008:68).

Arminius died in 1609, but his followers delivered a remonstrance to the authorities, trying to coerce them into calling a synod meeting to discuss the need to update and contextualise the church's existing creeds (Beeke 1999:96). The remonstrance had three sections: firstly, an explanation why it was written; secondly, an outline of their theology; and thirdly, a request for the state's support in dealing with the matter (Coetzee 2018:2). Uytenbogaert published a second document in 1610 with the title Tractaat over het ambt en gezag der overheid (Pont 1994:97). This document lured the authorities to intervene by ascribing a higher authority to the state than the church. Calvinists responded with a contraremonstrance - also calling for a synod meeting to resolve the matter.

John Oldenbarnevelt, the pensionary (landsadvocaat) of the Netherlands and advisor to Prince Maurice of Orange, oversaw domestic and foreign affairs. He responded to the plea from both sided and arranged a formal conference in 1612. The Remonstrants were hoping to promote tolerance, but the Calvinists wanted conformity. The conference was a failure, resulting in Oldenbarnevelt instructing both groups to simply go on with their lives and be tolerant of one another (Groenveld 1996:172), hoping that the matter would blow over. Gomarus and his followers were unhappy, as they saw this as a victory for the Remonstrants. The continuing theological and political debate, which ensued between the Calvinists and Arminians, escalated to the point of threatening the stability of some Dutch provinces. When Gomarist ministers were stripped of their posts by magistrates, favouring the Remonstrants, public rioting broke out (Gunn 2013).

Prince Maurice had no real interest or understanding of the predestination debate that was raging on, but decided to side with the Calvinists in 1617 purely for political gain. This was a significant political shift of power and he fired many Remonstrants from their political positions - some were even executed (Dreyer 1997:42-43). With Maurice's support for the Calvinists, Oldenbarnevelt and the magistrates tried to prevent a synod meeting, knowing that Maurice and the Calvinists would win and the Remonstrants would be branded as heretics (Israel 1998:421-426). Notwithstanding 
this opposition, Prince Maurice ordered the convening of a national synod to resolve the conflict that has been raging between the Remonstrants and the Calvinists (Groenveld 1996:173).

\section{Political background}

To understand the events surrounding the Synod of Dordrecht, one must reflect on the Dutch War of Independence that lasted 80 years (1568-1648). The war started 2 years after William I, Prince of Orange, became the Netherlands' leader. His army of 30000 soldiers had significant victories over Spain (Thatcher 2004:189). Only 3 years after the States General of the Netherlands signed the Declaration of Independence from Spain in 1581, William was assassinated by the Spanish (Thatcher 2004:190-197).

He was succeeded by Maurice of Nassau who was quite capable and was assisted by his mentor, John Oldenbarnevelt. As time passed the relationship between the two waned: Oldenbarnevelt preferred diplomatic negotiations with Spain, while Maurice had a deep-seated resentment against the Spanish. The breakdown in their relationship came to a climax in 1609 when Oldenbarnevelt, as Landsadvocaat, signed the Twelve Year's Truce with Spain. Maurice was vehemently opposed to this, and subsequently, turned his back on Oldenbarnevelt (Devreese \& Van den Berghe 2008:48).

The growing Calvinist support for Maurice, led Oldenbarnevelt to side with the Remonstrants (Israel 1998:431). This was an unfortunate turn of events, because the political struggle and the religious struggle were mostly independent up to this point; now an unhealthy symbiosis came into being between politics and religion (Voogt 2009:500). Maurice's support of the Calvinists was politically driven; their siding with him was religiously driven. It was a matter of the enemy of my friend is my enemy. Maurice did not want peace with Spain, and the Calvinists did not want the strong influence of Spain's Roman Catholicism. This coalition was united against Spain, but for different reasons: it was a coalition based on mutualism where both parties benefited (Paracer \& Ahmadjian 2000:6), and it was rather obligatory in nature with both the symbionts entirely dependent on one another for survival (Douglas 2010:4).

\section{Economic background}

On the economic front there were also powerful role players. A significant gap existed between the merchant class and the clergy, and commoners. Like Oldenbarnevelt, the merchants desired peaceful relationships with Spain, which would be beneficial for their trade relations - this brought them into conflict with Prince Maurice. The clergy strongly rejected peaceful engagement with Spain because of the threat of Roman Catholicism. They spent the preceding 100 years fighting the Roman Catholics; they were not eager to have to negotiate with them again. Most of the commoners sided with the Calvinists in this matter.
A national synod was the ideal opportunity for Maurice to secure victory over Oldenbarnevelt, the Remonstrants and the merchant class. 'If Maurice was going to have a war it would be a war with Spain, not a Dutch civil war, and so the Remonstrant defeat would have to be swift and decisive' (Gunn 2013:5). Maurice prepared the way for a favourable outcome of the Synod: he had Oldenbarnevelt and Hugo Grotius arrested and magistrates who supported the Remonstants were removed and replaced with pro-Calvinist ones. By the time the Synod convened, the outcome was just about decided.

\section{Synod meetings}

Thirteen Remonstrant leaders were invited to the Synod to defend their doctrine. They hoped that the Synod would allow them to debate the matter with their counterparts. This was not allowed, which lead to clashes between the two camps. The Remonstrants bravely tried to defend their views, and during the 23rd session, Episcopius gave a lengthy, powerful speech (Bangs 1996:72-73). Despite this, the constant conflicts between the two groups overshadowed the early Synod meetings (Sinnema 2011:314). One can understand the frustration of the Remonstrants: they were outnumbered, they were already branded as heretics and they were treated as transgressors who had to defend themselves against the force of a synod of about 100 members.

The French Huguenot churches were also invited, but for political reasons King Louis XIII prohibited them from attending (Maag 2018). Unable to participate, they sent a message to the delegates, urging the Synod not to get stuck on the remonstrance, but to come to a common understanding (Sinnema 2011:320). Sadly, this plea fell on deaf ears - the mutual suspicion of both parties blinded their judgement and affected the outcome of their encounter at Dordrecht.

On 01 January 1619, the States General intervened in the conflict and warned the Remonstrants to either cooperate or risk being ejected from the Synod. It was significant that this resolution came from the state and not from the church delegates who attended the Synod - implementing Maurice's resolve to deal with the matter swiftly. When the Remonstrants refused to cooperate, they were dismissed from the Synod on 14 January 1619, leaving the Synod to proceed without any Remonstrant presence.

This is one of the weaknesses of the imperial, colonial mindset: get rid of the opposition and decide for yourself what is best. Instead of two groups with dogmatic differences working towards a solution, one was expelled and the other made all the decisions. This is a disastrous approach to any negotiation - be it the Arminian or Calvinist debate, or the process of decolonising the curriculum.

\section{The outcome}

The Synod lasted 128 days and 180 sessions. By the time the Synod concluded, the Arminians were condemned, and the 
five points of Calvinism were clearly defined. As a result, 200 Remonstrants were banished, Grotius was given a lifesentence (but managed to escape with the help of his wife), and Oldenbarnevelt was falsely convicted of treason and beheaded. Despite a public outcry against his execution, Maurice stuck to his decision; he could not afford his political rival to gather renewed support.

Notwithstanding the severe ramification of the Synod, it did not have a lasting effect: Maurice died in 1625 and his brother, Frederick Henry, took over. Calvinism was still the official religion of the Netherlands, but Frederick had a tolerant religious approach. He allowed the Remonstrants back into the Netherlands, which led to them planting numerous churches and teaching their views unhindered. Even abroad the effects of the Synod lost its impetus and King James I of England, who personally appointed their delegates to the Synod, later withdrew his support for the Synod's decisions and prohibited the public preaching of Dortian theology (Strehle 1989:21-22). Questions need to be asked about the effectiveness of this effort to purge the Reformed church from the views of Arminianism. Today the Calvinist or Arminian debate is as unresolved as it was 400 years ago.

The Arminian challenge, which the Reformed church faced in the 1500's and the early 1600's, shows similarities to the current challenge of decolonisation and Africanisation of education with its polarisation between different parties. Theological education is drawn into this discussion alongside other academic disciplines, necessitating a response. Learning lessons from the way in which the Arminian challenge was handled, can prepare the way for an Africanised missional hermeneutic that will prevent the same mistakes from being repeated. We now briefly turn to an investigation of the demand for a decolonised curriculum.

\section{Decolonisation of education in South Africa \\ Missiology and decolonisation}

Niemandt (2019) states that it is no surprise that mission studies is influenced by contextual changes like decolonisation. The reason is that mission studies is inherently sensitive towards, and aligns itself, with contextualisation. This positions missiology ideally as the spearhead of theology in the thrust to transformation. This can be seen in new theologies of mission that are emerging. Niemandt (2019) lists a few:

\footnotetext{
... a new appreciation of mission from the margins, liberation theology and the associated discourses on decoloniality, the maturity of a theological consensus on the missio Dei, contextual awareness and practice and deep engagement in contextuality and the explosion of missional ecclesiology (and especially the concept of missional church). (p. 2)
}

These new missiological approaches directly or indirectly offer a critique on the current colonial or postcolonial structure of the theological curriculum.
Goheen (2016:7) points out that the church and its mission were dominated by a colonial slant during the last two centuries. Similarly, nearly four decades ago, Bosch (1982:16) warned about the colonial approach to mission studies and mission. We cannot deny that missionary work and the spread of colonialism went hand-in-hand. Every renewal and modification (from the colonially-biased inside-out) to mission theology and practice in response to calls for decolonisation are 'little more than superficial modernizations and adjustments' (Goheen 2016:7).

\section{Colonial heritage}

Molefe (2016:32) refers to a campaign in 2015 by some South African students and academics as the beginning of a thrust to decolonise the curriculum at universities (Wingfield 2017). The goal was 'ending the domination of Western epistemological traditions, histories and figures'. The students demanded an end to dominant 'white, male, Western, capitalist, heterosexual, European worldviews' and the introduction of other South African, African and global 'perspectives, experiences [and] epistemologies' as the central tenets of the curriculum, teaching, learning and research in the country (Heleta 2016). The students want to purge South Africa of the whiteness in society, economy and at universities; whiteness represent the superior attitude of white civilisation and development, and the marginalisation of black people (Sardar 2008:xiii).

Dissatisfaction was expressed about two matters: firstly, the lack of transformation in higher education; and secondly, the slow transformation after apartheid. Jacobs (2016) calls the settlement between the apartheid regime and the African National Congress a '... series of political, social and economic deals in which the racial inequalities of apartheid and wealth disparities largely remain intact and which benefits whites in general.' Nel (2011) states further:

The current expressions of empire show that the core structures of oppression have been left intact, only to be translated in the context of a new set of historical factors. (p. 168)

Higher education entities are seen by many as the last 'colonial outposts' (McKaiser 2016). 'There is something profoundly wrong when ... syllabuses designed to meet the needs of colonialism and apartheid should continue well into the liberation era' (Mbembe 2016:32). According to Ramoupi (2014:271), higher education in South Africa still reflects colonial and apartheid worldviews and is detached from the lived experiences of the black majority.

Colonisation included political control and exploitation of resources (Mamdani 1996:17) as well as the conviction that they were doing their subjects a favour by 'civilizing' them (Mamdani 1996:4; McEwan 2009:220; Mudimbe 1985:181). Historically, South African universities were founded by European settlers to serve their own interests. Graduates on South African soil were assured of an education comparable to that of their European counterparts. In this 
regard the possibility of learning something from Africans was not even considered. That is why the continuing suppression and marginalisation of African perspectives in the education system upholds historical racial divides and white supremacy.

Bunting (2004:40, 52) points out that white Afrikaans universities fully supported apartheid and that it advantaged the ruling minority. Therefore, '... decolonisation is about the consciousness and rejection of values, norms, customs and worldviews imposed by the [former] colonisers' (Césaire 2000:89). Decolonisation should be done by Africans, for Africans, in Africa (Ngugi 1981:87). Garuba (2015) suggests two approaches to decolonising the curriculum in South Africa: firstly, simply add new African themes to the existing curriculum. This seems artificial, because the teaching philosophy does not change; secondly, rethink how the curriculum is constituted and make meaningful changes.

\section{Decolonisation versus Africanisation}

A decolonial curriculum calls for a negation of a Westerncentric knowledge orientation and an embracing of various knowledge forms, including African, indigenous, ArabIslamic, Chinese, Hindu, Indo-American, Asiatic and Western. This is an intercultural understanding of humanity where cultures and their knowledge systems are respected (Santos 2014). Decolonisation, according to Nkoane (2006) involves:

... the re-invigorating of Africa's intellectuals, and the production of knowledge which is relevant, effective and empowering for the people of the African continent, and more particularly, the immediate African societies that the universities serve. (p. 49)

Mashau (2018) explains further:

On the question of whether we should choose between 'decoloniality' and 'Africanisation', it remains clear that the struggle of decoloniality is not divisive in nature. It is not necessarily an antithesis of coloniality but one that seeks to foster Afrocentric prescriptions to life in an uncompromising manner. African renaissance should remain at the heart of any decoloniality project. In addition, for us to understand issues raised, we should not shy away from engaging the black theology of liberation and discern from those voices from the margins as to how we should move forward in terms of racial reconciliation in this country. (p. 6)

Maluleke (2000:26) warns that there is no united, homogeneous Africa or African identity - 'there are and should be many and various ways of being an African'. That is why it is important to reflect on the meaning of Africanisation. Mashabela (2017) refers to Maluleke's definition (1998) of Africanisation, as 'liberation of all Africa and all Africans' - especially the poor people, the black people and the women. According to Mashabela 'Africanisation promotes human rights and dignity in order to' empower people 'spiritually, politically and socioeconomically'. He also quotes Ramose's (1998:iv) definition that 'Africanisation is a conscious and deliberate assertion of nothing more or less than the right to be an African'.

\section{Decolonisation as diversification}

On Monday, 21 January 2019, basic education minister, Angie Motshekga, called for a "more "decolonised" education system in South Africa - saying the current system needs to be amended to allow for diversification' (Businesstech 2019). This resonates with the demands by students over the last few years. What exactly these students mean is not always clear: on different campuses demands range from the inclusion of more African subjects to a completely new curriculum devoid of any traces of colonialism. Motshekga seems to support the first option, calling for more diverse subjects, because the current system is 'very colonial, British, academic' (Businesstech 2019).

Mbembe's views (2016:35) correspond with the views above, namely that European or other traditions cannot remain the centre of the university - Africa should become the centre. He warns, however, that decolonisation should not reject these traditions either. Even the Department of Education (2008:92) conceded that a decolonised curriculum should not neglect global knowledge systems and contexts. Ruddock (2018) highlights the futility of trying to erase Europe and the USA from the map in our decolonisation efforts. 'Doing so would mean that we have learnt nothing about the issue of discrimination, and simply replaced one set of exclusionary power relations with another.' Decolonisation should contribute to the expansion of our worldviews - not a narrowing of it. The multiplicity of different worldviews should be encouraged.

\section{Nel (2011) puts it well:}

In this context, the challenge and struggle for postcolonial missiology clearly seems to be asking the new questions about the postcolony, positioning the procedures in the current antiracist and imperialist struggles, and invoking all our histories, our moments of grace but also of disgrace. This might be the only way in which to exorcise those spirits that might otherwise keep haunting us all. (p. 12)

In conclusion one must note that the call from university students to decolonise the curriculum is not a uniquely African phenomenon. Similar calls have gone out from students in the USA and England (Wingfield 2017). Decolonisation is one the most seminal political, international and cultural issues of the contemporary world (Devenish 2013:310). Niemandt (2017:210) agrees that the decolonial discourse is also a "glocal" issue, that is, both recognising the broader discourses in theology, but also the construction of a localised theology'.

It is further of interest that decolonisation is also not a new concept in South Africa: on 31 May 1961, the Republic of South Africa came into being, which marked the beginning of a very definite process of decolonisation from Britain. The National Party came into its own in the 1970's in this regard, implementing sweeping constitutional and political changes. Regrettably, this was imposed by the white minority on their black counterparts without negotiation or collaboration 
(Devenish 2013:332). The outcome of this decolonisation was Afrikaner nationalism and imperialism with territorial segregation - something that had its roots in British colonial policy in the province of Natal (Devenish 2013:322). We would do well not to repeat the same mistakes as we work towards a decolonised and Africanised future.

\section{Culture}

Africanisation of theology should ask how the gospel relates to and plays into local narratives and theologies (Niemandt 2017:210). In other words, how does the missio Dei translate into our context? The decolonisation discourse should focus on an intercultural approach to education and theology (Niemandt 2019). We now turn our attention to important cultural aspects of interpersonal engagement.

\section{Cultural perspectives}

When challenges arise within a multicultural, multireligious society, we need to be sensitive to cultural diversity. Culture consists of all the things humans learn after they are born, which enable them to function effectively in their environment. We are all instructed from birth to conform to the patterns of behaviour that our society deems appropriate. By the time we become inquisitive, we have already been encultured, which determines our worldview and value system.

Studying cross-cultural perspectives have at least four benefits: firstly, understanding and interpreting ourselves in our own sociocultural matrix; secondly, understanding and interpreting those to whom we go in their sociocultural matrix; thirdly, understanding and interpreting the Bible, couched as it is in the cultural patterns of other times and places; and fourthly, understanding how best to communicate a message given to us in cultural forms other than our own to people who live by customs and assumptions different to ours (Kraft 2011:9, 13). Have the opponents in the Calvinism or Arminian debate adopted such an approach, the outcome might have been radically different. It goes without saying that the process of decolonisation or Africanisation of the curriculum can also greatly benefit from such an approach.

Every society has its own cultural lifestyle. We cannot live without such structuring; at least, no group or people have yet been discovered without culture (Kraft 2011:31). Culture may be defined as the design a people live by and the legacy that individuals inherit from the group. Or, to be more specific, we may see a culture as a society's complex, integrated coping mechanism, consisting of learnt, patterned concepts and behaviour, plus their underlying perspectives (worldview) and resulting artefacts (material culture) (Kraft 2011:38).

Racism is an example of a cultural interpretation of racial differences where a people with one set of racial traits sees themselves as superior to another group without those traits. Racism is therefore a type of ethnocentrism that, like other types, has no scientific validity. This fact, however, does not cause it to go away (Kraft 2011:111). Anthropology sees all cultures as essentially equal. There is no evidence of one culture being superior to another - where one culture excels in one area, another excels in another; it is foreign to the field of Anthropology to line cultures up from supposedly inferior to superior - as Westerners have often done.

Popularly ... westerners have looked at the cultures and the peoples of the Two-Thirds World and often called them 'primitive' or 'underdeveloped' because they don't do things the same way we do. (Kraft 2011:7)

A story was told of four blind men who touched different parts of an elephant and then described the elephant. Which of them was wrong and which of them was right? All were responding to something real that they touched; technically none of them was wrong in their description, but none understood the whole elephant (Kraft 2011:17).

This is the problem: no matter how sincere and trustworthy we are, as human beings, we never see the whole picture as God sees it. We always see in part and dimly (1 Cor 13:12). Yet we often ignore this limitation and lock ourselves into specific understandings of reality, dogmatically asserting them as if we knew the mind of God. Then we come across somebody who sees it differently, and we cannot deny the possible validity of that person's perspective. (Kraft 2011:17)

\section{Cultural persistence and progression}

There is a simultaneous, continuous process at work in the persistence of culture and its progression: the desire to keep things like they are, and the necessity to adapt. People are always changing their cultures - what is important is knowing how and why it changes. The answer lies partly in the fact that culture refers to the structured customs of people; society refers to the people themselves. It is this pressure from people (societal pressure) that forces others to observe their customs, while the lack of such pressure leaves them free to make different choices. Culture has no power to press for conformity; the power lies with society (Kraft 2011:37).

Cultural change is common and natural, but when it changes too rapidly and on a large scale, it creates problems. It disrupts people's sense of security and satisfaction with their way of life. Such disruption can lead to a sociocultural crisis, followed by breakdown. This is what happened between Arminians and Calvinists in the 17th century. The official church wanted to maintain the status quo and to defend their doctrine in obedience toScripture (e.g. 1Tm 6:3; Tt 2:1). The challenge from the Remonstrants was just too radical for their comfort and the required change too drastic. This is also what happens in colonialism when one culture takes control of a geographical area and exercises control over its inhabitants.

Normally, cultural change happens at a slow rate, but in our present world the rate of change is rapid, and it keeps on accelerating - especially under the influence of ideas that 
come from the West. This leads to insecurity, particularly for those who favour slow change. Different types of cultural change can be discerned: firstly, revolutionary change is the most rapid and is sudden and disruptive; secondly, cultural drift is a slower type of change when minor cultural alterations take place over a long period of time; thirdly, a long-term trend is less extensive than cultural drift, as it only affects one or several aspects of the culture; and fourthly, short-term change may be called a style or a fad.

One of the most dramatic challenges is the historic accident. These are abrupt and unpredictable events - unguided and often widespread in nature. War is a good example. The colonialist takeovers of non-Western societies during the 19th century is another tragic example as well as devastating volcano eruptions, earthquakes, floods and fires. The process that people go through as they adapt to, and adopt parts of the cultural system of another people, is called acculturation.

When this happens rapidly, people tend to go through the following stages: initially, there is a negative attitude towards the new practices and its acceptance; secondly, there is then an increased acceptance by the more daring; thirdly, if the process continues, it leads to a wholehearted acceptance of the new, and quite a bit of the traditional culture is rejected; and fourthly, after some time in stage three, disillusionment sets in for those who gave themselves over to the new culture and became an elite group. They realise that they are not able (or allowed) to fully participate in the society that they tried to enter. Kraft (2011) says:

The elite, who a few years earlier eagerly sought to identify themselves with the ways of the West in dress, education, food and politics, and who often deprecated their own culture and its achievements, now lead their people in a search to discover the essence of their traditional cultural forms. (p. 368)

One problem with colonial conquest is that it is carried out with an attitude of superiority. The colonists are the more powerful - the educated and civilised. They take over a territory from supposedly inferior beings, underserving of the freedom of choice. The worldview, culture and intellectual ability of the colonised do not matter - in fact these thing do not even exist in the mind of the colonist.

Maluleke (2007) uses the story of Rahab in the Bible to affirm this:

Furthermore, we have noted that Rahab is without religion, without culture, without history, without soul and without self consciousness. Her invaders are human; she is 'a thing that is, but only insofar as it is nothing'. Yet her invaders con her into thinking otherwise. With the invaders presence, she thinks that she graduates from nothingness into being something. And yet it is the very deal with her invaders which seals her fate as a 'thing' and a 'non-I'. She is of course 'a thing of value' insofar as she is a tool of and for imperialism and colonisation. Rahab 'possesses life, property, and body as if they were alien things'. She, her land and her people can therefore be invaded with impunity. Like Africa and Orientalism, Rahab is an invention an idea and an imagined myth of the coloniser. (p. 506)
Worldview is at the heart of culture and entails the paradigmatic assumptions, valuations and allegiances that underlie culture. The ideal society would operate in a healthy manner with these functions carried out effectively and the entire society pervaded with a sense of equilibrium and cohesiveness (Kraft 2011:435). Note that the biblical term world (e.g. 1 Jn 2:15-16; 1 Jn 5:4; Rm 12:2; Tt 2:11-12; Ja 4:4) is not the same as the human structures that we call 'culture'. If this were true, we would have to reject all aspects of culture as evil. And if this were true, we would be puzzled that, throughout the Scriptures, God uses cultural structures to connect with different people. It is not the structures that we must not conform to - it is the way people use, and especially misuse, the structures. We need to guard against being enslaved by cultural forms. As believers we should not simply follow the practices and standards of our society, but rather recognise that God enables and empowers us to live above such standards; our lifestyle should transcend the lifestyle of people around us (Kraft 2011:358-359). This is the ideal of the missio Dei.

\section{Cultural crisis}

We noted earlier that societies change. Often these changes take place too rapidly and on too large a scale. The result is that people's sense of security and satisfaction is disturbed. This disruption can lead to, in the first place, sociocultural crises followed by breakdown - maybe war, natural calamity, or the imposition of the customs and worldview of some foreign entity. Secondly, it necessitates a search for regrouping; the ideal resolution of the crisis, and thirdly, the society's survival of stage two and the subsequent formulation of a new steady state and a return to relative equilibrium. A simple model of this process of worldview transformation can be presented as follows:

\section{Old steady state $\rightarrow$ Crisis situation $\rightarrow$ New steady state}

People usually consider their customs and cultures to be correct, sacred, or even absolute. Still, it must not be imposed on others. Our Christian witness challenges both ourselves and other societies to live as Jesus did in what might be called 'Kingdom normalcy' (Kraft 2011:451). Preserve whatever is usable of your heritage (as Jesus did), but freely supplement it by reinterpretation, altering, or replacing what is not suitable. This will lead to growth in your relationship with Christ and redeem as much as possible of your cultural heritage for Christ (Kraft 2011:452).

After the Synod of Dordrecht, the Remonstrants were banned from ministry and from the Netherlands. This was the crisis that challenged their old steady state. In desperation, they later started their own church: The Remonstrant Brotherhood. This gave them some equilibrium in a new steady state. The Calvinists said the founding of the Remonstrant Brotherhood proved that the Remonstrants were never interested in unity, theological debate or finding common ground (Voogt 2009:504). Episcopius insisted that their 
approach had always been one of seeking mutual ground, but that they have reached a dead end because of the oppression and rejection by the Counter-Remonstrants despite the State's earlier appeals for mutual tolerance.

As if a victory for the Calvinists was not enough, the Remonstrants were killed and banned - almost completely obliterated. In South Africa, through colonisation, the inhabitants of the land were pushed aside and made subject to foreigners taking over their land. Colonisation is not interested in cohabitation; it wants to control, to take over, to rule and oppress. But to rule is not enough. Their subjects are dehumanised and treated like worthless 'things' in Maluleke's terms. This is an untenable situation, and sooner rather than later one can expect an uprising by the oppressed to claim back their liberty and humanity.

When common ground is not found, and tolerance and mutual understanding is not promoted, it leads to animosity and hostility. The Remonstrants did not want to split from the church and tried their best to find a solution. When it became clear that they would not be heard or taken seriously, it drove them over the edge, and they started a church to express their beliefs. This is a crucial lesson for the current Africanisation debate. Far too long Colonialist and Apartheid authorities bullied their opponents into submission. Like the Remonstrants, they are now rising and rebelling against such injustices.

It is imperative for the church in South Africa, and especially the white church, not to respond to this challenge with the same defensiveness as 17 th century Calvinism, but to engage with role players and to suggest directives on societal challenges and doctrinal issues, which are exegetically and doctrinally sound. This is even more critical in our postmodern era where there is a growing negligence or apathy regarding doctrine; Paul's word to Timothy seems rather applicable today: 'For the time will come when men will not put up with sound doctrine' (2 Tm 4:3). The church will do well to get involved and to encourage mutually beneficial conversations to take place. Where the church supported and established colonial supremacy, either directly or indirectly, it must now fight it as agents of the missio Dei.

\section{Towards a Missional Hermeneutic Theoretical framework}

Four hundred years after the Synod of Dordrecht, the debate between Calvinists and Arminians still rages on. Olson (2006:243) suggests principles that will promote a fair and fruitful debate between supporters of these two views. We could also apply Olson's principles to the debate on decolonisation and Africanisation:

- Before responding to the other, make sure you have studied their view and understand it as well as possible.

- Do not assault a straw man (Olson 2006:243). This happens when people aim their attacks on often unfounded caricatures of the other's viewpoint.
- Both sides should be willing to admit their weaknesses and shortcomings:

- If we point out apparent inconsistencies in the other party's views and argue that inconsistency shows weakness, we should not pretend that our own view is free of such flaws. (Olson 2006:243).

- Both sides should refrain from making assumptions about the other - assumptions that might be speculative or false. This happens when one strings together some of their viewpoints and concludes that: 'this is the logical consequence of their belief' (Olson 2006:244).

Kraft (2011:359) points out the following about intercultural engagement (we will do well to keep that in mind when we reflect on and engage in the decolonisation of the South African curriculum):

- Each culture is relative to other cultures. Every culture is tempted to idolise its culture and treat it as universally binding - to the detriment and harm of others.

- Each party to a relationship must have their own voice and the right to speak without the threat of censure and with the assurance of being respected and valued; this implies forming voluntary relationships with people often across cultural, linguistic and ethnic boundaries.

- Expect new light to break through as a result of intercultural relationships. The biblical vision of redemption is that people of different races, languages and cultures will be gathered around the throne of God (Rv 5:9-10). Note that diversity is not suspended, but rather embraced (Arles 2010:103-104).

- A new perspective (a renewed mind) leads to changes in our habitual behaviour. All sociocultural change starts with changes in the minds of individuals. As missiologists, we are interested in change; we want people to change in ways that will enable them to serve Christ better. It is important, however, that these changes cause as little disruption as possible. Therefore, we must learn as much as we can about cultural change: what causes change, what happens when people change their cultures, et cetera.

When we reflect on intercultural encounters, our model should be Jesus himself. He embodied the missio Dei and demonstrated how cultural barriers can be crossed:

- He identified with his receptors. Just like Jesus was incarnated into the society that he wanted to reach, we need to be willing to enter sympathetically into the receptor's way of life.

- Jesus was receptor-orientated. His primary concern was that those who listen to him and watched him would have a decent chance to understand him and to respond to his message. He spoke a language they could understand and used cultural forms that they were familiar with.

- Hegave himself to his hearers in two-way communication: he did not do all the talking, but was open to questions and discussions. 
- His communication went beyond verbal communication. He demonstrated the message. 'If you have seen me you have seen the Father' (Jn 14:9).

- Jesus did not have to demand respect, but earned it.

- Jesus did not minister to people in general, but dealt with specific people. Although his message was for all mankind, he took the time to communicate it individually.

- He also spoke into specific situations, contextualising his message.

- He refrained from information overload.

- People were challenged to self-discovery through his teaching. Instead of systematically transferring his whole message to people, he revealed it in smaller parts and allowed them to discover truths from there.

- Jesus trusted his receptors and sent them into the world to continue with the preaching of the Good News (Kraft 2011:443-444).

Jesus can take over this world forcefully and rule with an iron sceptre if he wants to - he is in fact God. He must simply give the command and legions of angels will forcefully colonise the world. Yet, he gave up equality with the Father to become one of us; humbling himself even to the extreme of the cross (Phlp 2:6-8). And then he said: 'As the Father has sent me, I'm sending you' (Jn 20:21). The mission of God is our mission too.

\section{Decolonising the mind}

The start of decolonising education in South Africa is the decolonisation of peoples' minds (Dladla 2019). In his Mail \& Guardian article, entitled Look at the kwerekwere in the mirror, Maluleke (2016:21) questions black South Africans' inconsistency in identifying who the amakwerekwere [foreigners] are. He points out how black South Africans use European ideas to distinguish themselves from the fellow African amakwerekwere: in the hierarchical notions of blackness, the South African black person is presumed to be the lightest-skinned and thus occupies the top spot on the pyramid. This is no different to white South African citizens who, until recently, still made a distinction between the uitlander and the burger or boer.

Maluleke uses Francis Nyamnjoh's book, \#RhodesMustFall: Nibbling at resilient colonialism in South Africa (2016), to illustrate his point. Nyamnjoh argues that white people are among the more recent amakwerekwere to enter South Africa - hence the reference to Cecil John Rhodes in his book. Yet, South African blacks only refer to other blacks from Africa as amakwerekwere, and not to whites. Maluleke (2016:21) calls this 'the self-hating conundrum of Afrophobia'. He asks if the South African born-frees finally connected the dots to realise that Rhodes was as much a kwerekwere as the foreign victims of contemporary xenophobia attacks.

Maluleke (2016:21) concludes his article with the notion that we need to embrace the ironies and contradictions of the past, present and future. 'Rhodes is not only "out there" but also "in here".' The only way Rhodes can fall, is when he falls inside all of us. The kwerekwere is the citizen and the citizen is the kwerekwere. Maluleke challenges his readers that, to spot the kwerekwere, one must look at the person in your mirror. I conclude with Maluleke's (2016:21) closing statement in his article: 'Whoever you may be, reach out to your inner kwerekwere and let us start building expanded and dynamic notions of citizenship together.' This kind of mind change is where fruitful engagement starts.

\section{Towards an African missional hermeneutic}

Reflection on the decolonisation of the curriculum, and in our case, the theological curriculum, needs to be driven by a suitable missional hermeneutic that reflects on the theological curriculum, the Bible and the contemporary context. This needs to be a truly African hermeneutic if we want the decolonisation of the curriculum to succeed. Africa has a contribution to make: 'African theological approaches have bidden farewell to hermeneutical innocence' (Maluleke 2000:32). Nkoane (2006) argues that we need:

... the reinvigorating of Africa's intellectuals, and the production of knowledge, which is relevant, effective and empowering for the people of the African continent, and more particularly, the immediate African societies that the universities serve. (p. 49)

Students need African experiences: the teaching style, examples used, models, interpretations and concepts need to be Africanised. It is not only the source of knowledge that must be questioned, but also who researches and teaches it (Webbstock 2017:9).

If theologians wait for politicians to take the lead in finding solutions to the decolonised curriculum - as was the case with the Synod of Dordrecht - we are in for the same result. The church has an indisputable role to play and must take initiative in intercultural mediation. Decolonisation and Africanisation is nothing new: throughout the Bible and church history the church has grappled with the gospel's reception and adaptation in different eras and contexts. If Maluleke is right that missions and missionaries promoted colonialism, then it is time for missiology to take responsibility for its part in this injustice and right its historical wrongs.

\section{The centrality of missiology}

Although all theological disciplines communicate faith, what sets missiology apart is that it communicates faith across the boundaries of cultural meaning-systems to non-Christians traditionally referred to as pagans or Gentiles. Missiology is the study of the church's boundary-crossing: boundaries in both the temporal and geographical sense (Arles 2010:55-56). Missional hermeneutics is therefore very important as Arles (2010) argues:

... mission is not just a matter of understanding the other but also of transmitting the faith. Communication relates to faith from the perspective of the sender, hermeneutics relates to faith from the perspective of the recipient. (p. 57) 
Intercultural theology is the exchange of thoughts and learning from one another - although this dialogue is mostly problematic and conflictive (Arles 2010:60).

What works against a missional hermeneutic, is that mission is no longer the heart of theological training - be it in the minority world or in the majority world (Mashau 2012:1). In fact, in many instances, missiology does not even feature in theological institutions. This is unfortunate, as missiology covers the entire scope of theology and is the theological field that analyses and describes the church's past, present and future life. It is imperative that missiology regains its central place in the theological curriculum. Niemandt (2019) argues that the near universal consensus on missio Dei will accomplish this and will shape the nature of theology and the study of missiology.

Missio Dei characterises God and the community of believers who belong to him. Newbigin (1989:222-233) sees the church as a missional community and as a hermeneutic of the gospel: not only does the church proclaim the gospel; it is the gospel. Missiology asks how the expansion and implantation of the church through the centuries can best be accomplished in each new context. The ability of the church to adapt and to reinvent itself is exactly what a missiological hermeneutic contributes to the debate of decolonisation.

\section{Stripping colonial theology of its innocence}

Decolonisation of education, especially in South Africa, must start with an understanding of the colonial framework. Niemandt (2019) mentions four elements of coloniality: firstly, it is an epistemic framework that privileges Western thought and worldview over its non-Western counterparts with the premise that the West is superior; secondly, coloniality establishes Eurocentric socio-economic and political hierarchy; thirdly, the prosperity cult that is sweeping through Africa is aform of global capitalism and coloniality; and fourthly, colonial mission was performed from the centre to the periphery - from the privileged to the marginalised.

The intellectual control has been in the hands of colonial and postcolonial imperialists far too long. To be confronted with the colonial framework, we must listen to the voices of those who were on the receiving end of colonial oppression. We might not like what we hear; in wilful ignorance I made myself believe that colonialism was state-driven and that missionaries simply capitalised on this opportunity to bring the gospel to the unreached. Yet, '... missionaries are never an innocent factor in mission ... we are speaking of a continuing reality deeply rooted in the practices of the colony and the postcolony' (Maluleke 2007:513). Maluleke challenged me with his provocative view of Rahab as a story of imperialism, conquest, occupation and even the 'beginnings of colonisation'. He (Maluleke 2007) sees her story as a metaphor for the land that the Israelites were about to invade:

Her complicity with her invaders and conquerors; her awe for and submission to them, as well as her hasty and eager 'settlement deal' with them is mind-boggling. Surely, she cannot be real ... Her behaviour, her actions and words, are all loaded with the logic of imperialism and the fantasy of colonialism. The deal she strikes with her invaders - as with all the deals between the conqueror and the vanquished - is a most hollow one. To save her life she sells her soul, her land and her people. She is therefore not equal to her invaders who only have to promise to spare her life and that of her family. (p. 505-506)

\section{Maluleke (2007) refers to a well-known saying:}

When the white man first came to our country, he had the Bible and we had the land. He said, 'let us pray to God'. We closed our eyes and joined him in prayer. When we opened our eyes at the end of the prayer, we saw that we now had the Bible and he had the land. (p. 512)

\section{He (Maluleke 2007) adds:}

Indeed the Bible and Christianity have been powerful media in the hands of subjects of both the colony and the postcolony ... The Bible has provided a common language between the coloniser and the colonised, the ruling classes and the rulers. Through it, the poor, the voiceless and those who represent them have managed to occasionally get through to the rich. But it has also strengthened and cemented relations between the rich and those poor trying to break out of poverty. (p. 517)

Black theologians have pointed out that 'the Bible is not innocent'. What will always haunt us is that the Bible was used in conquest. Therefore, postcolonial mission is very difficult. Maluleke (2007) continues:

In the postcolony, religion, especially Christianity, is part of the problem. Christian mission, as experienced by many Africans since the 15th century has been part of the colonisation. The Bible is the colonial text par excellence. Indeed, Christianity is, in many places, the colonial religion ... The scandal is that the Bible and the Christian faith were employed in the facilitation of conquest [now] he had the land, we had the Bible. (p. 521)

\section{The war for survival}

As humans, we are prone to conflict when it comes to selfpreservation. Therefore, it is fitting to close with an important contribution by Kraft (2011:451-452) that fits in well with the missio Dei: Since God and his kingdom is our supreme value, we should engage in the war between him and Satan. This battle is not - as some early Western missionaries thought - a battle between our 'Christian' culture and pagan cultures that have been corrupted by Satan to such an extent that they need to be replaced. Such missionaries assumed that God has somehow purified their Western cultures so that they had the right and duty to impose it on people whose societies were dominated by Satan. They saw their own cultural orientation as an appropriate way to bring pagans to Christ. This approach proclaimed: 'Civilize in order to evangelize!' (Kraft 2011:451). We should avoid this negative view of non-Western societies and their cultures. As we engage in encounters with people from all races, we anticipate the day when a multitude too great to count will gather before the throne of God, from every nation, tribe, people and language, worshipping the Lamb together! (Rv 7:9). 
This is fruitful soil for a missional hermeneutic of missio Dei. In his own mission, God overcomes the opposition and strangeness of man and reconciles us to him (Col 1:21-22); the missio Dei also draws humans closer to fellow humans. Differences are reconciled in light of the unifying character of missio Dei. A missiological hermeneutic underlying decolonisation must break away from the missio coloni and become again missio Dei.

\section{Acknowledgement Competing interest}

I declare that I have no financial or personal relationships which may have inappropriately influenced me in writing this article.

\section{Author's contributions}

P.H.J.L. declares that he is the sole author of this research article.

\section{Ethical consideration}

This article followed all ethical standards for carrying out research without direct contact with human or animal subjects.

\section{Data availability statement}

Data sharing is not applicable to this article as no new data were created or analysed in this study.

\section{Disclaimer}

The views and opinions expressed in this article are those of the authors and do not necessarily reflect the official policy or position of any affiliated agency of the authors.

\section{References}

Arles, S. (ed.), 2010, Towards an intercultural theology: Essays in honour of Jan A.B. Jongeneel, Centre for Contemporary Christianity, Bangalore.

Bangs, C., 1996, 'Arminius, Jacobus', in H.J. Hillerbrand (ed.), The Oxford Encyclopaedia of the Reformation, vol. 3, pp. 72-73, Oxford University Press, New York, NY.

Beeke, J.R. (ed.), 1999, Doctrinal standards, liturgy, and the Church order, Reformation Heritage Books, Grand Rapids, MI.

Bosch, D.J., 1982, 'Theological education in missionary perspective', Missiology 10(1) 13-34, viewed 15 July 2019, from https://doi.org/10.1177/009182968201000102

Botha, S.J., 2008, 'Arminus, Jakob (1560-1609)', in F. Gaum, A. Boesak \& W. Botha (eds.), Christelike kernensiklopedie, p. 68, Lux Verbi BM, Wellington.

Bunting, I., 2004, 'The higher education landscape under apartheid', in N. Cloete, P. Maassen, R. Fehnel, T. Moja, H. Perold \& T. Gibbon (eds.), Transformation in higher education: Global pressures and local realities in South Africa, pp. 35-52, Kluwer Academic Publishers, Dordrecht.

Businesstech, 2019, 'Minister wants to "decolonise" education in South Africa' Businesstech, viewed 15 July 2019, from https://businesstech.co.za/news/ lifestyle/294654/minister-wants-to-decolonise-education-in-south-africa/.

Césaire, A., 2000, Discourse on colonialism, Monthly Review Press, New York.

Coetzee, C.F.C., 2018, 'What can we learn from Dordrecht for a possible authentic confessio Africana?', In Die Skriflig/In Luce Verbi 52(2), a2376. https://doi. org/10.4102/ids.v52i2.2376

Department of Education, 2008, Report of the ministerial committee on transformation and social cohesion and the elimination of discrimination in public higher education institutions, Final Report, Department of Education, Pretoria.

Devenish, G.E., 2013, 'Cutting the apron strings: The South African experience of decolonisation', The Journal for Transdisciplinary Research in Southern Africa 9(2), 309-340. https://doi.org/10.4102/td.v9i2.209

Devreese, J.T. \& Van den Berghe, G., 2008, 'Magic is no magic': The wonderful world of Simon Stevin, WIT Press, Ashurst, Southampton.
Dladla, N., 2019, 'Decolonising the university in South Africa: A precondition for justice' Academia, viewed 23 April 2019, from https://www academia edu/1031311/ Decolonising_The_University_In_South_Africa_A_Precondition_for_Liberation

Douglas, A., 2010, The symbiotic habit, Princeton University Press, Princeton, NJ.

Dreyer, W., 1997, 'Die ontstaan van belydenisskrifte gedurende die sestiende en sewentiende eeu', HTS Teologiese Studies/Theological Studies 53(4). https://doi. org/10.4102/hts.v53i4.1779

Garuba, H., 2015, 'What is an African curriculum?', Mail \& Guardian, 17 April, viewed 15 June 2016, from https://mg.co.za/article/2015-04-17-what-is-an-africancurriculum

Goheen, M.W., 2016, 'A history and introduction to a missional reading of the Bible', in M.W. Goheen (ed.), Reading the Bible missionally, pp. 3-27, Orbis Books, Maryknoll, NY.

Groenveld, S., 1996, 'Oldenbarnevelt, Johan van', in H.J. Hillebrand (ed.), The Oxford Encyclopedia of the Reformation vol. 3, pp. 172-173, Oxford University Press, New York.

Gunn, D., 2013, 'A historical account of the Synod of Dort', The 1024 Project, viewed 15 July 2019, from http://1024project.com/2013/11/13/a-historical-account-ofthe-synod-of-dort/

Heleta, S., 2016, 'Decolonisation of higher education: Dismantling epistemic violence and eurocentrism in South Africa', Transformation in Higher Education 1(1), viewed 15 July 2019, from https://doi.org/10.4102/the.v1i1.9

Israel, J., 1998, The Dutch republic: Its rise, greatness, and fall: 1477-1806, Oxford University Press, New York, NY.

Jacobs, S., 2016, 'Student protests and post-apartheid South Africa's negative moment', Africa is a country, viewed 10 July 2019, from http://africasacountry. com/2016/05/student-protests-and-postapartheid-south-africas-negativemoment

Kraft, C.H., 2011, Anthropology for Christian witness, Orbis Books, Maryknoll, New York.

Maag, K., 2018, 'Impact amid absence: The Synod of Dordt and the French Huguenots', In die Skriflig/In Luce Verbi 52(2). https://doi.org/10.4102/ids.v52i2.2340

Maluleke, T.S., 1998, 'The Africanization of theological education: Does theological education equip you to help your sister?', in E. Getman \& J.R. Cochrane (eds.) Africanization, liberation \& transformation in theological education: Report of the third annual workshop of the National Initiative for Contextual Theological Education, pp. 9-18, Salty Print, Johannesburg.

Maluleke, T.S., 2000, 'The rediscovery of the agency of Africans: An emerging paradigm of post-cold war and post-apartheid black and African theology', Journal of Theology for Southern Africa 108, 19-37, viewed 18 July 2019, from https:// www.academia.edu/32281224/THE_REDISCOVERY_OF_THE_AGENCY_OF_ AFRICANS_An_Emerging_Paradigm_of_Post-cold_War_and_Post-_Apartheid_ Black_and_African_Theology

Maluleke, T.S., 2007, 'Postcolonial mission: Oxymoron or new paradigm', Swedish Missiological Themes 95(4), 506, viewed 16 July 2019, from https://www. academia.edu/29877422/Tinyiko_Maluleke_-_Postcolonian_Mission_ Oxymoron_or_New_Paradigm.pdf

Maluleke, T.S., 2016, 'Look at the kwerekwere in the mirror', Mail \& Guardian, June 10-16, viewed 16 July 2019, from https://mg.co.za/article/2016-06-09-look-atthe-kwerekwere-in-the-mirror

Mamdani, M., 1996, Citizen and subject: Contemporary Africa and the legacy of late colonialism, Princeton University Press, Princeton, NJ.

Mashabela, J.K., 2017, 'Africanisation as an agent of theological education in Africa', HTS Theological Studies 73(3), 1-9, viewed 18 July 2019, from https://doi. org $/ 10.4102 /$ hts.v73i3.4581.

Mashau, T.D., 2012, 'A reformed perspective on taking mission and missiology to the heart of theological training', In die Skriflig/In Luce Verbi 46(2), 8 pages. http:// dx.doi.org/10.4102/ids.v46i2.64

Mashau, T.D., 2018, 'Unshackling the chains of coloniality: Reimagining decoloniality, Africanisation and Reformation for a non-racial South Africa', HTS Teologiese Studies/Theological Studies 74(3), 4920. https://doi.org/10.4102/hts.v74i3.4920

Mbembe, A., 2016, 'Decolonising the university: New directions', Arts \& Humanities in Higher Education 15(1), 29-45. https://doi.org/10.1177/1474022215618513

McEwan, C., 2009, Postcolonialism and development, Routledge, New York, NY.

McKaiser, E., 2016. 'Epistemic injustices: The dark side of academic freedom', IOL: DCS Oosthuizen Academic Freedom Memorial Lecture, Rhodes University, Grahamstown on 30 May 2016, viewed 05 July 2019, from http://www.iol.co.za/ news/epistemic-injustices-the-dark-side-of-academic-freedom-2029747

Molefe, T.O., 2016, 'Oppression must fall: South Africa's revolution in theory', World Policy Journal 33(1), 32. https://doi.org/10.1215/07402775-3545858

Mudimbe, V.Y., 1985. 'African gnosis philosophy and the order of knowledge: An introduction', African Studies Review 28(2/3), 149-233. https://doi. org introduction,

Nel, R.W., 2011, 'Postcolonial missiology in the face of empire: In dialogue with Frantz Fanon and Steve Bantu Biko', Studia Historiae Ecclesiasticae 37, suppl., 157-170, viewed 17 July 2019, from http://uir.unisa.ac.za/handle/10500/5657

Newbigin, L., 1989, The gospel in a pluralist society, Eerdmans, Grand Rapids, MI.

Ngugi, W.T.O., 1981, Decolonising the mind: The politics of language in African literature, East African Educational Publishers Ltd., Nairobi.

Niemandt, C.J.P., 2017, 'The prosperity gospel, the decolonisation of theology, and the abduction of missionary imagination', Missionalia 45(3), 203-219, viewed 12 July 2019, from https://doi.org/10.7832/45-3-199 
Niemandt, C.J.P., 2019, 'A missional hermeneutic for the transformation of theological education in Africa', HTS Teologiese Studies/Theological Studies 75(4), a5406. https://doi.org/10.4102/hts.v75i4.5406

Nkoane, M.N., 2006, 'The Africanisation of the university in Africa', Alternation 13(1), 49-69.

Olson, R.E., 2006, Arminian theology: Myths and realities, IVP Academic, Downers Grove, IL.

Paracer, S. \& Ahmadjian, V., 2000, Symbiosis: An introduction to biological associations, Oxford University Press, Oxford.

Pont, A.D., 1994, 'Chapter 9: "Die sinode van Dordrecht (1618-1619)"', in HTS Teologiese Studies/Theological Studies 97-111, viewed 18 February 2019, from https://hts.org.za/index.php/hts/article/view/4451

Ramose, M.B., 1998, 'Foreword', in S. Seepe (ed.), Black perspectives on tertiary institutional transformation, pp. iv-viii, Vivilia Publishers, University of Venda, Thohoyandou.

Ramoupi, N.L.L., 2014, 'African research and scholarship: 20 years of lost opportunities to transform higher education in South Africa', Ufahamu: A Journal of African Studies 38(1), 269-286

Ruddock, P., 2018, 'Decolonising education in South Africa', IOL, viewed 10 July 2019 , from https://www.iol.co.za/news/opinion/decolonising-education-in-southafrica-13679313
Santos, B., 2014, Epistemologies of the South: Justice against epistemicide, Paradigm, Boulder, CO.

Sardar, Z., 2008, 'Foreword to the 2008 edition: I think it would be good if certain things were said: Fanon and the epidemiology of oppression', in F. Fanon (ed.), Black skins, white masks, pp. vi-xx, Pluto Books, London.

Sinnema, D., 2011, 'The Canons of Dordt: From judgment on Aminianism to confessional standard', in A. Goudriaan \& F. van Lieburg (eds.), Revisiting the Synod of Dordt: 1618-1619, pp. 313-333, Brill, Leiden.

Strehle, S., 1989, 'The extent of the atonement and the Synod of Dort', Westminster Theological Journal 51(1), 21-22.

Thatcher, O.J., 2004, The library of original sources: (9th to 16th Century), vol. 5, The Minerva Group, Milwaukee.

Voogt, G., 2009, 'Remonstrant-counter-Remonstrant debates: Crafting a principled defence of toleration after the synod of Dordrecht (1619-1650)', Church History and Religious Culture 89(4), 489-524. https://doi.org/10.1163/187124109X506204

Webbstock, D., 2017, 'Decolonising the curriculum: Stimulating debate', Briefly speaking 3, viewed 24 May 2019, from https://www.che.ac.za/sites/default/files/ publications/BS\%203\%20Curriculum\%20Decol\%20-\%20Final.pdf

Wingfield, B., 2017, 'What "decolonised education" should and shouldn't mean', in The Conversation, viewed 15 July 2019, from http://theconversation.com/whatdecolonised-education-should-and-shouldnt-mean-72597 